$\begin{gathered}\text { EPiC Series in Education Science } \\ \text { Volume 1, 2017, Pages 219-226 }\end{gathered}$
$\begin{gathered}\text { AUBEA 2017: Australasian Universities Build- } \\ \text { ing Education Association Conference 2017 }\end{gathered}$

\title{
Form and Performance: Tall Concrete Structures and Apartment Quality in Melbourne's Residential Towers
}

\author{
Giorgio Marfella ${ }^{1 *}$, Andrew Arthur Martel ${ }^{1 \dagger}$, Alexandra Gower ${ }^{2 \ddagger}$ \\ and James Helal ${ }^{1 \S}$ \\ ${ }^{1}$ University of Melbourne \\ ${ }^{2}$ RMIT University \\ giorgio.marfella@unimelb.edu.au, aamartel@unimelb.edu.au
}

\begin{abstract}
Does the structural configuration of tall buildings affect the quality of apartment design? The architecture of tall buildings relies strongly on quantitative inputs. Yields of development, overturning moments, dynamic responses and lift-waiting periods are, for instance, items numerically measurable. The built form of tall buildings has to work within these strict and seemingly unchallengeable constraints. Yet, these same parameters should not be an impediment for spatial quality. Four case studies, taken from the recently proliferating stock of high rise apartment towers in Melbourne, are used to highlight the missed opportunities that follow from a partial application of performance-based design, where façade concepts, structural and construction inputs prevail over those of an overarching spatial integration. The mandate of performancebased design, if driven chiefly by mono-disciplinary concerns, remains incomplete, unless qualitative concerns, able to discern broader criteria for end-users, integrate as a high-level priority in the design process. A sample of apartments currently under construction in Melbourne's CBD indicates that the emphasis on marketing, structural and construction demands is a key driver of the current built outcomes, relegating spatial quality and functionality of the dwellings produced to a third rank of priority. Some recently introduced built form controls with public benefit provisions make Melbourne an ideal environment to test, evaluate and discuss within the industry a new range of typologies. However, such guidelines should start by acknowledging a broader and more evidence-based concept of innovation, design quality and performance in design.
\end{abstract}

\footnotetext{
* Lecturer in Construction Management and Architecture

${ }^{\dagger}$ Early Career Academic in Construction Management and Housing

* PhD Candidate

${ }^{\S}$ Lecturer in Construction Management
} 


\section{Introduction}

While tall buildings in Central Business Districts are generally associated with global corporate business and prestige office buildings, residential towers, are becoming the dominant tall building typology of many cities worldwide. The central city of Melbourne, for example, has become, after the Global Financial Crisis, the epicentre of a boom of high-rise and residential construction activity. In 1995, the twenty tallest buildings of the city ranged in height from 130 metres to 265 metres. These, with the exception of one mixed-use office and hotel building, were all commercial offices. By 2020, considering the projections of the Council on Tall Buildings and Urban Habitat (CTBUH, 2017), the tallest 20 buildings of the city will range in height from 240 metres to 325 metres, and among these, only three buildings - completed between late 1980s and early 1990s - will be office buildings. The rest of the tallest buildings in the skyline will be mono-functional residential - at times with a small component of commercial floor space at lower levels - or mixed-use residential and hotel towers. By the end of the 2010s, Melbourne could become one of the cities with the highest number of buildings taller than 200 meters in the planet, outnumbering in prospect - with a building stock comprised in prevalence by residential condominiums - global cities like Chicago, Kuala Lumpur, Tokyo and Singapore (Marfella, 2016).

In the context of this radical urban transformation, and following growing concerns related to excessive density and poor built form outcomes, the State Government of Victoria has introduced in 2016 the Central City Built Form Review, which includes a set of initiatives to improve the built form outcomes of inner city high-rise developments (DELWP and Hodyl, 2016). Non-owner-occupiers purchase the great majority of central city apartments in Melbourne are as an investment and the separation between owner and resident, combined with the primacy of economic yield and asset price growth in purchasing decisions, have raised questions about the spatial quality and functional liveability of the apartment stock. In 2017, the Victorian Government has therefore amended the State's planning provisions to include also a newly formulated Better Apartment Design Standards, for apartment towers more than four storey high. (DELWP and Office of the Victorian Architect, 2016).

Some of the central issues raised by this local debate pertain to the broader question of what determines quality and innovation in design vis-à-vis the degree of prescription (or lack thereof) in urban regulatory frameworks. Stemming from the recent events of the City of Melbourne, and using the built-form outcomes of a selection of local projects, this paper highlights and examines the existence of a predominant structural solution, which has been deployed in Melbourne's residential towers. The argument presented is that lack of integration of structural and development drivers with the architectural design intent plays a key role for the limitation on the size, quality and ergonomic outcomes of the living spaces inside the buildings.

\section{Methodology}

In central Melbourne, building proposals larger than 25,000 square metres in gross floor area fall under the direct control of the Planning Minister of the State of Victoria, who receives comments and recommendations from the City of Melbourne planning officers and City Council via meetings and deliberations held by committees such as the current Future Melbourne Committee (FMC). Using public information retrieved from meeting minutes of FMC, and drawings submitted for planning approval, a sample of four for tall buildings projects approved in central Melbourne over the last five years were selected. Three out of the four projects were submitted for approval before the recent introduction of new built-form controls, and one after. 
There are many factors, both qualitative and quantitative, that can contribute to the spatial quality of apartments, which here cannot be covered in depth for reasons of space. Focus is given hereafter on the specific issue of minimum room dimensions and apartment layouts vis-à-vis the configuration of structural elements, such as columns and shear walls. The limitations of this study are constrained within a small pilot sample of four buildings and by a merely qualitative assessment of the structural layout of the buildings, which for this study could not be corroborated by a quantitative-based of the engineering performance of the typology identified or with a comparative assessment with other structural typologies.

The typical floor plans of four towers were analysed in order to identify the structural design typology employed with the scope to identify patterns and relationship between the structural grid and the residential spaces. Selected individual apartments were also analysed to highlight quantitative and qualitative features of the internal layouts of the units, seeking to identify the influence that structural members such as shear walls and columns, may have on spatial layouts. The four project samples were chosen in different areas of the inner city, where new residential building clusters under development respond to different types of market demand. The sample includes two up-market 'luxury' projects, one designed by a notorious international architect and located at the western end of city (Case Study A), and another designed by a local architect and located in Southbank (Case Study $\mathrm{B})$; the other two projects are lower-end speculative projects located in the north-western area of the $\mathrm{CBD}$ and were designed by another local architect (Case Study $\mathrm{C}$ and D).

\section{Case Study Analysis}

The characteristics of the structural grid employed on the residential floor plates of the four buildings in consideration are shown in Table 1. Three of the four case studies (A, C and D) are approximately rectangular with a North-South and East-West orientation, which reflects the orientation of the city grid where they are located. The maximum span, centre-to-centre, between shear walls ranges from 8.4 metres to 6.75 metres on the longer axis, and from 6.8 metres to $4.5 \mathrm{~m}$ on the short axis. Case Study A has a typical floor shape nearly square, although articulated by projections, which result in different structural grids along the North-South and East-West axes. Case Study A uses large shear rectangular columns in conjunction with structural circular columns, a solution not dissimilar to the shear walls-only approach used in the other three buildings. The Maximum distance between columns is in this case $8.5 \mathrm{~m}$ along North-South axis and approximately $7 \mathrm{~m}$ along the East West axis.

Case Studies A and B have a fairly constant façade to core depth of habitable space around a central service core, which varies from 9.7 to 9.8 metres and from 14 to 14.6 metres respectively. Case Studies C and D are more elongated in plan and have depth that varies from 6.6 to 10 metres and from 7.9 to 12.1 metres respectively. The slenderness ratio of the towers ranges from approximately 5 (Case Study A) to 8 (Case Study B) and the length of the façade perimeter for a typical residential floor ranges from $122 \mathrm{~m}$ (Case Study D) to $174 \mathrm{~m}$ (Case study B). Finally, the number of residential apartments per typical floor ranges from 12 (2 one-bedroom units and 10 two-bedroom units, in Case Study A) to 18 (8 one-bedroom units and 10 two-bedroom units in Case Study B). The typical size of one-bedroom apartments across the case studies was between 45 to 50 square metres, and the one of two-bedroom apartments was 65 to 70 square metres.

\begin{tabular}{|c|c|c|c|c|c|c|c|c|}
\hline \multirow[t]{2}{*}{$\begin{array}{l}\text { Case } \\
\text { Study }\end{array}$} & \multicolumn{2}{|c|}{$\begin{array}{l}\text { Grid Span c-c } \\
(\mathrm{mm})\end{array}$} & \multicolumn{2}{|c|}{$\begin{array}{c}\text { Distance from Core } \\
\text { to Facade }\end{array}$} & \multirow{2}{*}{$\begin{array}{c}\text { Approx. } \\
\text { H/W } \\
\text { Ratio }\end{array}$} & \multirow{2}{*}{$\begin{array}{c}\text { Façade } \\
\text { Perimeter } \\
\text { m }\end{array}$} & \multirow{2}{*}{$\begin{array}{c}\text { Core } \\
\text { Area } \\
\mathrm{m} 2 \\
\end{array}$} & \multirow[t]{2}{*}{$\begin{array}{l}\text { No. } \\
\text { Apts. }\end{array}$} \\
\hline & $\mathrm{NS}$ & EW & NS & EW & & & & \\
\hline A & 8400 & 5451 & 9820 & 9695 & 5 & 128 & 224 & 12 \\
\hline
\end{tabular}


Form and Performance: Concrete Structural Efficiency and Apartment Quality ...

G. Marfella et al.

\begin{tabular}{|c|c|c|c|c|c|c|c|c|}
\hline B & 8510 & 7065 & 14020 & 14630 & 7 & 174 & 187 & 18 \\
\hline C & 6750 & 4500 & 6600 & 10000 & 8 & 133 & 194 & 14 \\
\hline D & 7000 & 6800 & 7910 & 12115 & 6 & 122 & 96 & 14 \\
\hline
\end{tabular}

\section{Error! Reference source not found.}

\section{Findings}

By comparing the spatial characteristics of the structure of these four buildings with the minimum room sizes indicated by the Better Apartment Design Standards of the State of Victoria (see Table 2), two sets of observations follow.

Firstly, the four buildings clearly present a consistent structural typology, which is defined by a central core and an array of shear wall dispersed around the floor plate. These shear walls are usually located well inside the habitable floor plate and they are disengaged from the perimeter of the building, where the edge is free to be articulated with curves, protrusions or indentations at will of the external architectural expression. This structural approach is in line with the structural typology and the construction methods used on a number of all-concrete and glass-clad residential towers that were recently completed in Melbourne. The concrete core (built with self-climbing jump forms) and the concrete shear walls (built in situ or precast) are completed by post-tensioned concrete flat slab construction. This structural typology satisfies profitable development mandates, where floor-to-floor height can be minimized and high-rise construction can progress with minimum risks by eliminating from the critical path the erection of vertical elements along the perimeter of the building.

\begin{tabular}{|l|c|c|c|c|}
\hline \multirow{2}{*}{} & \multicolumn{2}{|c|}{ Studio or One Bedroom Apartment } & Two or more Bedroom Apartment \\
\cline { 2 - 5 } & Minimum Width & Minimum Depth & Minimum Width & $\begin{array}{c}\text { Minimum } \\
\text { Depth }\end{array}$ \\
\hline $\begin{array}{l}\text { Main } \\
\text { Bedroom }\end{array}$ & 3000 & 3400 & 3000 & 3400 \\
\hline $\begin{array}{l}\text { Other } \\
\text { Bedrooms }\end{array}$ & - & - & 3000 & 3000 \\
\hline Living area & 3300 & $\begin{array}{c}10 \mathrm{~m} 2 \\
\text { minimum area }\end{array}$ & 3600 & $\begin{array}{c}12 \mathrm{~m} 2 \\
\text { minimum area }\end{array}$ \\
\hline $\begin{array}{l}\text { Ratio of Ceiling Height to Room } \\
\text { Depth }\end{array}$ & $\begin{array}{c}\text { Open Plan Layout (Kitchen-Living) } \\
\text { Maximum depth }\end{array}$ \\
\hline $\begin{array}{l}\text { Habitable } \\
\text { room }\end{array}$ & \multicolumn{2}{|c|}{$2.5: 1$} & \multicolumn{2}{c}{9 m (ceiling height 2.7 m min) } \\
\hline
\end{tabular}

Error! Reference source not found. 
Secondly, there is an evident relationship between the typical distances between shear walls observed in the residential floor plates of these case studies and the minimum dimensional criteria for rooms set by the Better Apartment Design Standards. The more spacious arrangements observed in the case studies, suggest that shear walls supporting flat slabs can rarely span beyond 8.4 to 8.5 metres. Two bedroom apartments are therefore not possible to be accommodated within such spans, unless the second bedroom is setback as a deep and narrow L-shaped 'saddleback' with a very restricted exposure along the façade. In all of the four case studies observed, two bedroom apartments are forced to work around the structural grid, with second bedrooms and bathrooms having to swallow thick, deep and shear walls in their interiors. This limited integration with structural elements often comes at odds with spatial quality along the corners of the buildings whereby apartments are not placed within discrete spaces between structural elements and are forced in a patchwork of spaces that does not bear a direct relationship to ideal patterns of use and distribution. By contrast, the layout of internal structural elements in the basements that house carpark structure responds with more success to the dimensions of the space required for the circulation of cars.

Furthermore, the Victorian design guidelines summarized in Table 2 set the stage for an ongoing proliferation of one-bedroom apartments, where a bedroom and living area can easily be placed adjacent to one another (satisfying minimum light/ventilation/views) with rooms sized at the minimum dimensions already observed in two of the four buildings analysed. In summary, the new controls seem well-fitted for the already established structural template of central core and internal shear walls.

\section{Discussion}

The definition of a tall building varies from place to place in terms of absolute height, but an accepted definition of this typology considers both physical aspects relative to a surrounding context such as height, proportions, slenderness, and the use of construction technologies that are specific and necessary for the typology in question. These last criteria reflects the fact that all tall buildings are a particular building typology governed strongly by a few key physical criteria, such as vertical circulation, and other performance criteria that are mostly structural, such as wind resistance and stiffness (CTBUH, 2011).

While some of the physical and technological constraints on tall buildings may be universal for all destinations of use, the drivers of architectural and spatial quality are diverse and vary significantly between commercial office and residential use. Commercial office spaces require maximum flexibility within the lettable area and favour open plan, column-free design on each floor. Such expectations of spatial quality are essential for rentability and determine that structural elements should work within such restraints. So, for example, in the case of a centre-core floor plate, the primary structural elements, apart from the core itself, are ideally located along the edge of the floor, typically in the form of a perimeter frame with stiff columns and edge beams, thus leaving any space between such frame and the core unobstructed by structural elements. This configuration is also conducive to regular and rectilinear perimeters and façades that, combined with column free interiors, are generally more desirable and rentable than irregular or geometrically hybrid perimeter profiles of the floor. Notwithstanding some exceptions, typological patterns of this kind can be observed in the tall office buildings of many cities worldwide, and they are a dominant characteristic of Melbourne's commercial tall building stock (Marfella, 2010).

By contrast, residential high-rise buildings are less dependent on column-free space, where primary structural elements can be located in the form of shear walls along party walls between units. This in turn, allows for more freedom of the architectural treatment of the façade, leading to the production of 'iconic' architectural imagery and becoming vehicle of effective marketing for the sale 
of the apartments (Gower, 2015). This opportunity of architectural expression stems from a number of factors, including the large percentage of apartment purchases by investors in central city housing markets, and the wide-spread practice of selling 'off-the-plan' in Australia, where developers are required to pre-sell a percentage of apartments in order to unlock the development finance required to construct the building (Martel, 2012). Structure, therefore, in the case of residential buildings is preferentially placed within the floor plate to allow for maximum flexibility with the façade, including curves, undulations, indentations and extrusions.

It is significant, however, that recent high-rise construction trends in Melbourne CBD have easily borrowed the overall physical appearances and technologies from the older generation of tall office buildings of the city, notably with the widespread adoption of unitised curtain walls of glass. But this knowledge transfer did not occur - for the detriment of apartment quality - with regard to the structural systems, which in the case of office buildings can rely to a well-established array of solutions able integrate architectural expression, user flexibility via open space, and structural efficiency with steel, concrete and composite elements. (Ali, 2001; Ali and Moon, 2007; Kowalczyk et al., 1995).

In view of these considerations, these case studies suggest the existence of a disconnection between architectural expression and structural engineering in contemporary tall residential buildings. These two central disciplines should be integrated to meet the specific physical and technological challenges of innovation that are implied by the very definition of a tall building and by the tradition of architectural engineering associate with this building typology. But the evidence of recent high-rise developments Melbourne indicates an historical counter-tendency, where the two disciplines have been relegated to fit into a minimum common denominator that satisfies above all development return and large-volume production, rather than innovation and production of spatial quality and high rise living to meet population growth.

\section{Conclusion}

The argument presented from these case studies is twofold: on the one hand, fears that lack of deregulation may stifle innovation seem unfounded for a building typology that, in a highly deregulated environment before the introduction of more prescriptive control, has already shown hardly any strategic elements of innovation and competitive variety. On the other hand, the introduction of 'better' criteria of spatial design for apartments and a control by authorities on built form in the case of tall buildings does not seem likely to encourage radical improvements on the local typology. Unless authorities are prepared to upset the current template of development and key stakeholders are prepared to embrace a broader notion of performance in design that starts with the integration of architectural expression with advanced structural engineering. These considerations require further inquiries on the dynamics of interactions between the different parties involved in tall residential buildings in Australia today (e.g. developers, designers and contractors), and the establishment of the extent that these parties are committed to engage in a coordinated effort for the delivery of projects according to the highest and most integrated interpretation of performance-based design.

\section{References}

Ali, M. M. (2001). 'Evolution of concrete skyscrapers: from Ingalls to Jin Mao', Electronic Journal of Structural Engineering, Vol. 1 (1), pp 2-14. 
Ali, M.M. and Moon, K.S. (2007). 'Structural developments in tall buildings: current trends and future prospects', Architectural Science Review, Vol. 50 (3), pp 205-223.

CTBUH (Council on Tall Buildings and Urban Habitat), (2011). 'Criteria for defining and measuring tall buildings',

http://www.ctbuh.org/TallBuildings/HeightStatistics/HeightCriteria_22017/tabid/7456/language/en-

US/Default.aspx, viewed: 28 April 2017.

CTBUH (Council on Tall Buildings and Urban Habitat), (2017). 'The Skyscraper Center, Melbourne, Australia', https://skyscrapercenter.com/city/melbourne, viewed: 28 April 2017.

DELWP and Hayball, (2016). Architectural Testing of Built Form Controls, Melbourne Hoddle Grid / Southbank. State Government of Victoria, Department of Environment, Land, Water and Planning (DELWP), Melbourne.

DELWP and Hodyl, (2016). Central City Built Form Review Synthesis Report, State Government of Victoria, Department of Environment, Land, Water and Planning (DELWP), Melbourne.

DELWP and Office of The Victorian Government Architect, (2016). Better Apartment Design Standards: New Apartment Design Standards for Victoria, State Government of Victoria, Department of Environment, Land, Water and Planning (DELWP), Melbourne.

Donn, M., Selkowitz, S. and Bordass, B. (2012). 'The Building Performance Sketch', Building Research and Information, Vol. 40 (2), pp 186-208.

Kowalczyk, R. M., Sinn R. and Kilmister M.B. (1995). Structural Systems for Tall Buildings: Systems and Concepts. McGraw Hill, New York.

Krem, M., Hoque, S.T., Arwade, S.R. and Breña, S.F. (2013). 'Structural configuration and building energy performance', Journal of Architectural Engineering, Vol. 19 (1), pp 30-40.

Fincher, R., (2007). 'Is high rise housing innovative? Developer's contradictory narratives of high rise housing in Melbourne', Urban Studies, Vol. 44 (3), pp 631-649.

Gower, A. (2015). The False Coin of Our Apartment Dreams: Value in Contemporary for Inner City Melbourne, Master in Architecture Thesis, University of Melbourne, Faculty of Architecture, Building and Planning.

Marfella, G. (2010). 'Five Speculative Points for a Building Type', in P. Tombesi and V. Chen (eds), AUBEA 2010: Construction Managment(s), proceedings of the 35th Australasian Universities Building Education Annual Conference, 7-10 July 2010, Melbourne, Australia, 1 (1), 1:16.

Marfella, G. (2016). 'The Future of Skyscrapers in Melbourne: from Hyper-Density to the Uplift Principle', in A. Wood and D. Malott (eds), Cities to Megacities: Shaping Dense Vertical Urbanism, proceedings of the CTBUH 2016 Conference, 16-21 October 2016, Shenzhen, Guangzhou and Hong Kong, China, pp 379-386.

Martel A., (2012). Eco-Oikos: an Investigation of Value in Recent High-density Student Housing in Melbourne, PhD Thesis, University of Melbourne, Faculty of Architecture, Building and Planning. 
Moore, T., Alves, T., Horne, R. and Martel, A., (2015). 'Improving Design Outcomes in the Built Environment through Design Review Panels and Design Guidelines', in proceedings of the State of Australian Cities Conference, 9 -11 December 2015, Gold Coast, Queensland.

Parsons, L. and Addison, L. (2017). 'Debating tall: Melbourne's New Skyscraper Guidelines: Too Restrictive?' Council on Tall Buildings and Urban Habitat Journal, (1), p 5. 